\title{
Entre primaveras e tempestades: a Editorial Universitaria de Buenos Aires e o violento começo da década de 1970 na Argentina
}

\author{
Caio Henrique Vicente Romero ${ }^{1}$
}

Resumo: Neste artigo, pretendemos analisar de que maneira os embates políticoideológico-culturais ocorridos em uma editora de livros argentina - a EUDEBA, Editorial Universitaria de Buenos Aires, ligada à UBA (Universidad de Buenos Aires) dialogaram com os diversos embates de mesma natureza que se deram nos complicados anos 1970 argentinos. O recorte engloba um delicado momento da história da Argentina, marcado por exacerbadas tensões entre grupos peronistas e antiperonistas - à esquerda e à direita - bem como por cisões e antagonismos internos a tais movimentos. A violência política foi uma das marcas do período, veio à tona de variadas e, muitas vezes, trágicas maneiras e sua presença está registrada em diversos âmbitos da sociedade argentina, entre eles o trabalho editorial exercido pela EUDEBA.

Palavras-chave: Argentina; Peronismo; História dos Livros.

\section{Between springs and storms: Editorial Universitaria de Buenos Aires and the violent beginning of the 1970s in Argentina}

\begin{abstract}
In this article, we intend to analyze how the political-ideological-cultural clashes that took place inside the Argentine book publisher EUDEBA - Editorial Universitaria de Buenos Aires, linked to UBA (Universidad de Buenos Aires) dialogued with the various clashes of the same nature that took place in the complicated Argentine 1970s. The cut includes a delicate moment in the history of Argentina, marked by exacerbated tensions between Peronist and anti-Peronist groups - at both sides of the political spectrum (left or right) -, as well as by splits and internal antagonisms between such movements. Political violence was one of the hallmarks of the period, came to the fore in a variety of and often tragic ways and its presence is registered in several areas of Argentine society, including the editorial work carried out by EUDEBA.
\end{abstract}

Keywords: Argentina; Peronism; Book History.

Artigo recebido em: 28/09/2020

Artigo aprovado para publicação em: 07/04/2021

\footnotetext{
${ }^{1}$ Mestre em História Social pela Faculdade de Filosofia, Letras e Ciências Humanas da Universidade de São Paulo (FFLCH-USP) sob orientação da Professora Livre-Docente Gabriela Pellegrino Soares. Atualmente, é professor da Educação Básica em São Paulo. Contato: caiohvr@gmail.com.
} 


\section{Introdução}

Nas disputas por poder dentro de uma sociedade encontram-se sempre diversos personagens e interesses e, na maior parte dos casos, as relações entre eles são complexas e apresentam muitos elementos aparentemente paradoxais. Adiante, pretendemos analisar de que maneira os embates político-ideológico-culturais ocorridos em uma editora de livros argentina - a EUDEBA, Editorial Universitaria de Buenos Aires, ligada à UBA (Universidad de Buenos Aires) - dialogaram com os diversos embates de mesma natureza que se deram nos complicados anos 1970 argentinos. O recorte engloba um delicado momento da história da Argentina, marcado por exacerbadas tensões entre grupos peronistas e antiperonistas - à esquerda e à direita bem como por cisões e antagonismos internos a tais movimentos. A violência política foi uma das marcas do período, e veio à tona de variadas e, muitas vezes, trágicas maneiras. Tal perspectiva nos parece instigante, dado que a publicação de livros era uma atividade cultural que, no período em questão, constituía elemento fundamental para a difusão de ideias e visões de mundo. Além disso, no caso da EUDEBA, o prestígio obtido nos anos iniciais da sua atividade e sua ligação com o Estado argentino - ainda que contasse com instrumentos jurídicos que tentassem minimizá-la - conferia a ela um lugar cobiçado entre as empresas culturais do país. Em 1973, durante a Primavera Camporista, assumiria a direção da editora um grupo de intelectuais ligados à esquerda peronista, iniciando uma jornada promissora, ainda que sob pesadas nuvens de ataques à direita e à esquerda, como analisaremos a seguir. Começaremos com uma breve apresentação da editora e em seguida passaremos à análise dos processos históricos em que esteve envolvida durante os violentos anos 1970 argentinos. 


\section{A editora}

A EUDEBA foi criada em 1958 e fazia parte de um processo de reorganização da UBA, naquele momento capitaneado por Risieri Frondizi, reitor da instituição. ${ }^{2}$ Frondizi fazia parte de um grupo de professores que assumiu protagonismo político dentro da universidade após a derrubada de Juan Domingo Perón em 1955. Tal grupo era composto por intelectuais majoritariamente antiperonistas e que possuíam perspectivas ideológicas que se encaixavam dentro do amplo espectro da esquerda - os intelectuais "acadêmicos", utilizando a categoria criada por Oscar Terán, que os opunha aos "críticos", que assumiriam posturas mais radicais à esquerda (TERÁN, 2013). Assumindo-se como reformista e reorganizador, o reitorado de Frondizi adotou práticas de inserção da universidade na sociedade argentina. Criou, por exemplo, o Departamento de Extensão Universitária, responsável por realizar eventos, palestras e cursos dedicados a atrair o público não acadêmico para a universidade. Além disso, foram criados a associação e os seminários para graduados, visando manter o vínculo entre a universidade e seus egressos.

Foi nesse contexto que emergiu no Conselho Superior da UBA a proposta posteriormente atribuída por Risieri Frondizi a si próprio - de criação de uma editora universitária. Surgia ali o embrião do que se tornaria a Editorial Universitaria de Buenos Aires - EUDEBA. Assim, a criação da editora associou-se a um discurso modernizador e de retomada de determinados ideais da Reforma Universitária de 1918 por parte da universidade, conectando-se, também, a uma tentativa de desperonização da UBA, marcada, no plano institucional, pelo expurgo de professores ligados ao peronismo e pela recontratação de professores expulsos nos governos de Perón. ${ }^{3}$ No dia 31 de maio de 1958, foi encaminhado a Risieri Frondizi um estudo que sugeria diretrizes e planos de ação para a criação da editora universitária.

\footnotetext{
${ }^{2}$ Risieri Frondizi era irmão de Arturo Frondizi, que assumiria o cargo de presidente da Argentina em maio de 1958.

${ }^{3}$ Um debate mais extenso sobre os processos de intervenção na UBA durante o primeiro governo de Juan Domingo Perón, bem como uma discussão mais detida sobre o processo de desperonização ao qual aludimos, encontra-se em NEIBURG, 1997.
} 
O estudo foi elaborado por ninguém menos que Arnaldo Orfila Reynal, importante intelectual e editor argentino. Orfila Reynal participara do processo de reforma universitária iniciado em 1918 na cidade de Córdoba, representara os estudantes argentinos no primeiro congresso internacional de estudantes realizado no México em 1921 e era, em 1958, diretor da editora Fondo de Cultura Económica (FCE) no México. Tais credenciais levaram Risieri Frondizi a contratá-lo para elaborar o projeto de criação da editora. Frondizi e o Vice-reitor da UBA, Florencio Escardó, apontaram que o modelo de edição conduzido por Orfila Reynal no FCE do México era o que mais se assemelhava ao que pretendiam criar na Argentina. O FCE mesclava o melhor de dois mundos: uma editora de grande sucesso comercial que possuía obras especializadas de grande interesse dentro do mundo acadêmico. (ÁLVAREZ (et alli), 2015).

A EUDEBA foi elaborada com uma proposta de difusão da cultura letrada para além dos limites da universidade - sem deixar de lado, entretanto, as necessidades acadêmicas da instituição. No projeto inicial da editora, ficava patente que o editor teria um papel de mediador cultural, dialogando com diferentes setores de dentro e de fora da universidade e elaborando estratégias que promovessem ações ligadas à didática e à extensão cultural. ${ }^{4}$

O lema escolhido pela editora para o início de suas atividades foi "libros para todos", pressupondo que o processo editorial da nova empresa não se restringiria às demandas da universidade. O primeiro gerente da EUDEBA, José Boris Spivacow, contribuiu para dar forma a tal projeto, com sua experiência anterior no mercado editorial e uma condução assertiva da editora no sentido de atribuir a ela um papel formativo em relação aos leitores: ampliar o público sem perder a qualidade dos títulos e a ligação com o meio acadêmico e intelectual. ${ }^{5}$ Desse modo, ao menos institucionalmente, a EUDEBA atrelava-se a uma postura reformista e compromissada com a difusão do livro que, entretanto, mantinha como uma de suas preocupações

\footnotetext{
${ }^{4}$ Para mais detalhes sobre o processo de criação da EUDEBA, ver SAGASTIZÁBAL, 2008 e ROMERO, 2012.

${ }^{5}$ O primeiro Gerente Geral da editora foi José Boris Spivacow. Sua condução da EUDEBA e a criação de outro bem sucedido projeto editorial argentino - o Centro Editor de América Latina (CEAL) - alçaramno ao status de um dos mais emblemáticos e referenciais editores do país. Para mais informações sobre Spivacow, ver MAUNÁS, 1995 e GOCIOL, 2010.
} 
centrais a demanda de edição universitária. Como qualquer projeto cultural, a editora apresentava-se como uma instituição híbrida, que misturava diferentes práticas e representações para atingir seu objetivo, construindo uma trajetória que não deveria prescindir de nenhum dos dois domínios. Seria possível levar libros para todos?

Entre as práticas elaboradas na tentativa de efetivar o lema da editora, destacouse a instalação de kioscos nas ruas da Argentina. Os kioscos eram bancas de vendas de livros construídas em lugares de grande movimento com o objetivo de divulgar e vender os livros da EUDEBA.

Os kioscos inseriam os livros no cotidiano de diversas pessoas que, de outra forma, não os acessariam. Na Memoria y Balance General - documento oficial produzido pela editora como uma espécie de "prestação de contas" para os acionistas e para a sociedade - do segundo exercício da editora (de 24 de junho de 1959 a 30 de junho de 1960), a iniciativa encontra-se descrita da seguinte maneira:

\footnotetext{
Estos quioscos instalados en las calles son un complemento de los propósitos enunciados al hablar de la Serie del Siglo y Medio, ya que con ellos se pretende poner el libro al alcance del hombre que habitualmente no entra en una libraría, para que lo vea y lo compre como compra una revista o un diario. $^{6}$
}

Tal alternativa constituiria, portanto, uma aplicação dos objetivos de difusão cultural e educacional para além dos limites da universidade. No arquivo central da UBA, obtivemos acesso aos primeiros boletins de informações da instituição. Tais boletins tinham por objetivo divulgar e integrar as ações acadêmicas e sociais da universidade e foram criados no mesmo contexto de reorganização pós-peronista. Folheando-os, encontramos na contracapa do boletim de número 18, publicado em novembro de 1960, os endereços de vinte e um kioscos espalhados por todo o país. A distribuição dos kioscos e a diligência da iniciativa - foram construídos 21 kioscos em dois anos de existência da editora - oferecem-nos indícios de que o lema libros para todos possuiu uma correspondência prática bastante interessante.

\footnotetext{
${ }^{6}$ Memoria y Balance General - segundo ejercicio - 24/06/59 al 30/06/60. Consultado no Fundo EUDEBA do Arquivo da Biblioteca Nacional Mariano Moreno.
} 
Nos anos iniciais da EUDEBA, as tiragens eram grandes - em sua maioria acima de 5.000 exemplares e foram publicados centenas de títulos importantes em áreas específicas das ciências, como Las bases físicas y químicas de la herencia, de George Wells Beadle (que esgotou rapidamente sua primeira tiragem de 7.500 exemplares), Introducción a la bioestadística, de H. Bancroft e Teoría pura de Derecho, de Hans Kelsen. Também foram publicados títulos que visavam divulgar aspectos de movimentos culturais e científicos para um público mais amplo, como Los maestros del jazz, de L. Malson e História del neutrón, de D. J Hughes. Tais títulos estavam organizados dentro de coleções, como Cuadernos, Ciencia Joven, Temas, Manuales e Lectores. A mais bem sucedida coleção do período inicial da editora, entretanto, foi a Serie del Siglo y Medio, que, lançada em comemoração aos 150 anos da Independência da Argentina, compilou livros de autores "históricos" da literatura argentina. Títulos como Episodios de la Revolución, de Bartolomé Mitre, Los siete platos de arroz con leche, de Luis Mansilla e Facundo - civilización y barbárie, de Domingo Faustino Sarmiento foram publicados em tiragens que facilmente superaram os 10.000 exemplares e que contavam em suas capas com ilustrações de importantes artistas argentinos. Não obstante, em consonância com o projeto original da editora, os livros eram vendidos nos kioscos e nas livrarias por preços acessíveis.

Como podemos observar, a EUDEBA adotou estratégias de produção editorial que traziam para a prática a tentativa de difundir o conhecimento letrado para diferentes camadas da população. Organização dos livros em coleções, edições em material rústico e com preço reduzido, capas e projeto gráfico atraentes, entre outras, foram características do processo de trabalho da editora. Tais preocupações aparecem concretizadas e condensadas no processo de publicação, em 1962 (dentro da Serie del Siglo y Medio), de uma edição do canônico poema de José Hernández, Martín Fierro, ilustrado pelo artista Juan Carlos Castagnino.

De acordo com um documento interno da editora, a expectativa acerca da publicação de Martín Fierro era a seguinte:

Impacto: por la calidad y cantidad de ilustraciones, por sus características físicas, por el precio de las ediciones populares y por la resonancia que las obras publicadas por Eudeba alcanzan en el público, se estima que ésta será, 
y con mucho, la edición más importante del Martín Fierro publicada hasta la fecha. $^{7}$

As práticas de edição popular da EUDEBA transformaram-se, no período de quatro anos entre a abertura da editora até a publicação do livro de José Hernandez, em um argumento utilizado para justificar os empreendimentos futuros do grupo. Esse é um indício de que os libros para todos atingiram, de fato, um elevado número de pessoas, permitindo que os editores sonhassem alto:

Tirada: de la edición popular del libro se hará una tirada inicial de 50000 ejemplares y de la carpeta una tirada inicial no inferior a los 5000; estas tiradas se estiman reducidas y se cree que habrá posteriores reediciones. De los libros y carpetas para vender en librerías, a crédito y a coleccionistas se harán ediciones mucho menores. ${ }^{8}$

Os membros do diretório da EUDEBA, em sua Memoria y balance general do ano de 1963, utilizaram o sucesso do Martín Fierro e de outra coleção de livros de arte da editora, Cuentistas y pintores, para defender seus valores editoriais e comprovar, de certa forma, o êxito do projeto editorial e comercial da EUDEBA, afirmando que tais edições:

a) Permiten que la obra de nuestros artistas adquiera una resonancia desconocida hasta ahora en nuestro país y en América toda. En efecto, en menos de ocho meses de las diferentes ediciones de libros y carpetas del "Martín Fierro" se imprimieron más de 200.000 ejemplares. [...] b) Estimulan la labor del artista: para el "Martín Fierro", Juan C. Castagnino ejecutó más de 200 originales y centenares de bocetos; para "Cuentistas y pintores", Alonso, Basaldúa, Batlle Planas, Berni, Castagnino, Policastro, Russo, Seoane, Soldi y Urruchúa ejecutaron 342 originales y cientos de bocetos. [...] c) Constituyen una vasta empresa de carácter didáctico y cultural; d) Dan prestigio al libro argentino y hacen conocer otros aspectos del labor que desarrolla la Universidad de Buenos Aires [...] Pero estas ediciones cumplen además una finalidad económica y financiera: a pesar de su reducido precio de venta, su altísima tirada y rápida comercialización han dado grandes utilidades y fuertes ingresos que permitieron a EUDEBA incrementar su programa fundamental de obras científicas. ${ }^{9}$

\footnotetext{
${ }^{7}$ Retirado de documento interno da EUDEBA datado de 03/07/1962. Consultado no Fundo EUDEBA do Arquivo da Biblioteca de La Nación Argentina.

${ }^{8}$ Ibidem.

9 Memoria y balance general - 1/7/62 - 30/6/63. Consultado no Fundo EUDEBA do Arquivo da Biblioteca de La Nación Argentina.
} 
Em primeiro lugar, os autores do texto ressaltam o caráter de difusão cultural cumprido pelas duas coleções. Além de levar obras de arte a um número imenso de pessoas, o documento ressalta que um dos méritos das coleções foi incentivar o trabalho e o reconhecimento de artistas argentinos. Ademais, o último trecho da citação revela a consciência, por parte dos protagonistas desse projeto editorial, da importância do sucesso mercadológico para que a editora se mantivesse. Ao mesmo tempo que são projetos de extensão cultural, as duas coleções de maior sucesso comercial naquele momento operam como financiadoras para que o outro - e principal - eixo de difusão cultural da EUDEBA funcione a contento: a publicação de obras científicas.

Não obstante, o cenário da editora mudou drasticamente em pouco tempo. Após o golpe de Estado de Juan Carlos Onganía, ocorrido em 1966, a EUDEBA passou por anos conturbados em que ocorreram sucessivas tentativas de desmontar a estrutura inicial planejada por Arnaldo Orfila Reynal e colocada em prática nos primeiros anos de existência da editora. As publicações e tiragens foram diminuídas, muitos kioscos foram fechados e as contas internas se deterioravam a cada ano.

\section{"EUDEBA no es una isla": os violentos anos 1970, a EUDEBA e a volta do peronismo ao poder na Argentina}

O golpe de Estado de 1966 coincidiu com a intensificação da radicalização política na Argentina. A efervescência de ideias vivenciada durante toda a década de 1960 desaguou nos anos 1970 com força total. Impulsionados pela deterioração do poder de compra dos salários e por uma grave crise provocada, entre outros aspectos, pela política econômica do governo Onganía, os sindicatos e o movimento estudantil se organizavam e aos poucos tomavam corpo greves e protestos. Em diversos momentos do mês de maio de 1969, sublevações estudantis ocorreram na cidade de Rosário, iniciadas pela resistência estudantil à intenção de privatizar o restaurante universitário. No primeiro enfrentamento, um estudante foi assassinado pela polícia. Ao longo do mês, outro estudante pereceu nos protestos (GARULLI (et alli), 2011, p. 138). A violência escalava rapidamente. 
Em 29 de maio de 1969, na cidade de Córdoba, os ativismos estudantil e operário se juntaram, dando início a um movimento de massas que marcou o início do declínio do governo de Onganía, o Cordobazo.

O Cordobazo foi um movimento de protesto composto por diversos focos e formas de ação. Entre 29 e 31 de maio, as ruas de Córdoba foram tomadas por manifestações, barricadas, fogueiras e fortíssima repressão policial. Mais de vinte pessoas morreram, por volta de quinhentas ficaram feridas e mais de trezentas foram detidas (ROMERO, 2015, p. 203). Em meados de 1970, Onganía foi substituído na presidência por Roberto Marcelo Levingston, que, por sua vez, seria substituído por Alejandro Agustín Lanusse em 1971. Ambos exerceram mandatos cada vez mais marcados pelo signo da violência explícita. ${ }^{10}$

O historiador Hugo Vezetti, ao escrever sobre a violência revolucionária na Argentina dos anos 1970, retoma uma reflexão de Hannah Arendt:

El poder, dice Arendt, requiere del "número", algo de lo cual puede prescindir la violencia, que depende sobre todo de los "instrumentos". Siempre, en términos políticos, la tentación de recurrir a la violencia nace de la pérdida de poder (VEZETTI, 2013, p. 64).

Tal citação, ainda que breve, sintetiza de maneira satisfatória o processo de aceleração e explicitação da violência que atravessava a Argentina nos anos 1970. A violência, que estava subjacente às relações políticas e sociais, aflora rapidamente e passa a ser enxergada por muitos atores políticos como a única forma de ação em um contexto de opressão e proibição da participação política. Significativo indício dessa situação foi a eleição do "terrorismo" como o personagem do ano de 1970 pela revista Panorama (CARASSAI, 2015, p. 66).

Em um contexto sociopolítico tensionado, cresce a polarização e a visão de que os atores políticos de oposição são inimigos. A historiadora Camilla Fontes de Souza afirma que,

\footnotetext{
${ }^{10}$ Sobre o Cordobazo e a violência política no período, ver: IZAGUIRRE, 2009; TCACH, 2012; e a recente pesquisa de doutorado de GONZÁLEZ, 2018. 
sob esta concepção totalizante, a designação "subversivos", atribuída aos militantes e grupos sociopolíticos, ganhou força no discurso institucional como caracterização ideológica daqueles que seriam os "inimigos da nação". Ao mesmo tempo [...], também seriam inimigos todos os que priorizavam os interesses privados sobre o bem público, os que "vendiam a pátria" para o capital internacional e, em suma, os que não faziam das "necessidades do povo" a prioridade da nação (SOUZA, 2013, p. 19).

Dessa forma, começaram a atuar no país grupos armados à esquerda e à direita. Pela esquerda, as principais organizações foram o Ejército Revolucionário del Pueblo (ERP) e o grupo Montoneros. O ERP, nascido de grupos trotskistas vinculados ao Partido Revolucionario de los Trabajadores (PRT), tinha sua luta guerrilheira inspirada pelo foquismo propugnado por Ernesto "Che" Guevara e pelos revolucionários cubanos. No caso dos Montoneros, juntava-se todo o arcabouço justicialista à crença na violência como meio para atingir os fins revolucionários (NOVARO, 2016, pp. 106-107). Carlos Altamirano definiu assim os grupos guerrilheiros de esquerda que surgiram na Argentina após 1969:

La convicción común a todos ellos era que el sistema de dominación vigente, de tipo semicolonial, reposaba en la violencia y que sólo otra violencia, que echara a andar una guerra que debía evolucionar como guerra popular, podría desenmascarar y, finalmente, derrotar a ese sistema que explotaba al pueblo y oprimía a la Nación (ALTAMIRANO, 2001, p. 90).

À direita, ocorreram ações de grupos comandados principalmente por organizações anticomunistas e por membros da direita peronista, ligados, em sua maior parte, ao grupo dirigido por Augusto Vandor.

Os assassinatos políticos, nesse cenário, transformaram-se em ferramentas privilegiadas de ação. De acordo com dados compilados pela investigadora Inés Izaguirre, houve um grande crescimento do número de mortos e desaparecidos no campo popular (da esquerda) a partir de 1969. Passou-se de seis mortes, em 1969, para 35 em 1972, bem como aumentou o número de militantes desaparecidos, de cinco, em 1970, para sete em 1972 (IZAGUIRRE, 2009, p. 86).

Como se pode notar, os grupos políticos ligados ao peronismo também estavam cindidos no início dos anos 1970. Por um lado, os peronistas de esquerda - que incluíam os Montoneros e a Juventude Peronista - passaram a encarar como objetivo a libertação 
nacional por meio da luta social - inclusive armada. Tal ação seria, em sua visão, a contribuição possível em uma luta solidária com o povo argentino, que permanecera fiel ao líder no exílio. A direita peronista - representada majoritariamente pelos sindicatos , por sua vez, condenava as ações armadas e defendia o fim das proscrições ao peronismo e a volta de Perón como forma de resolver as questões políticas e sociais.

Em 1970, membros do movimento peronista e de agrupamentos de esquerda dos mais variados matizes suspenderam temporariamente suas rivalidades para formarem uma frente intitulada La Hora del Pueblo, em que denunciavam o governo pela péssima situação social que grassava no país - a inflação voltara a subir e as condições de vida se deterioravam - e o acusavam de entregar as riquezas nacionais às potências estrangeiras. O grupo organizou dezenas de greves e atos de protesto, que aumentaram o alerta do governo militar. Por mais que Perón negociasse com Lanusse, as massas peronistas agiam cada vez mais autonomamente, ainda que não prescindissem de justificar seus atos pelas declarações - muitas vezes descontextualizadas - do líder no exílio. $^{11}$

Ao mesmo tempo em que aceitou desautorizar os movimentos guerrilheiros que agiam em seu nome, Perón nomeou para o Conselho Nacional do Justicialismo (órgão máximo do movimento político liderado por Perón) um dos chefes dos Montoneros, Rodolfo Galimberti. Além disso, o Partido Justicialista (PJ) fez parte da organização da FRECILINA (Frente Cívica de Liberación Nacional), que viria posteriormente a transformar-se na FREJULI (Frente Justicialista de Liberación Nacional), reforçando a tática da formação de frentes de oposição - que incluíam frações dos Montoneros e dos agrupamentos da esquerda peronista organizados em torno da chamada Tendência Revolucionária (TR) - para vencer o regime militar. Não obstante, Lanusse e Perón chegaram a um acordo - que passou por uma discreta visita do líder exilado à Argentina, em novembro de 1972 - e as eleições foram convocadas para março do ano seguinte.

\footnotetext{
${ }^{11}$ Após sua derrubada, em 1955, Perón passou dezoito anos exilado da Argentina, estabelecendo-se na maior parte do tempo na Espanha. De longe, o líder político permanecia entranhado na vida argentina e enviava, por meio de assessores pessoais, mensagens para as bases do movimento peronista. Tais mensagens eram interpretadas das mais diversas formas, ao sabor das circunstâncias políticas e dos interesses dos interlocutores.
} 
Para concorrer às eleições, a FREJULI - que englobava, naquele momento, as principais frações políticas do peronismo - lançou como candidatos a presidente e vicepresidente, respectivamente, Héctor Cámpora - ligado à esquerda peronista, em especial à Juventude Peronista - e Vicente Solano Lima - político do Partido Conservador Popular da confiança de Perón e ligado à direita peronista. De acordo com Camilla Fontes de Souza, a combinação dos candidatos "sintetizava o poder de fusão entre a esquerda e a direita, presentes internamente no peronismo. Mais do que uma união intraperonista, esta aliança era a expressão da possibilidade de união de distintas forças políticas sob um único projeto de nação, o projeto peronista" (SOUZA, 2013, p. 23).

No dia 11 de março de 1973, com 49,5\% dos votos, Héctor Cámpora venceu Ricardo Balbín, da União Cívica Radical - ${ }^{12}$ que obteve 21,3\% dos votos - e foi eleito presidente da Argentina. A consigna “Cámpora al gobierno, Perón al poder", que fora exaustivamente repetida pelos jovens peronistas durante a campanha eleitoral, tinha agora a chance de se concretizar. Após 17 anos de proscrição oficial, os peronistas voltavam ao poder.

Com a eleição do novo governo, a esquerda peronista foi tomada por grande empolgação operativa, em um processo que ficou conhecido como "Primavera Camporista”. Entre os dias 4 e 15 de junho de 1973, foram realizadas mais de quinhentas ocupações de escolas, universidades, fábricas e empresas em todo o país. Tinha-se a sensação de que o poder estava mais perto do que nunca e era necessário agir. Por outro lado, o ministério de Cámpora era formado por pessoas das mais variadas origens sociais e vertentes ideológicas, incluindo o ministro do Bem-Estar Social, José López Rega, um policial aposentado de ideologia conservadora que se aproximara muito de Perón durante o exílio e seria um dos porta-vozes do desejo do líder de que fosse controlada a "subversão" esquerdista. López Rega organizou grupos paramilitares que passaram a agir clandestinamente contra os agrupamentos de esquerda e depois foram consolidados na Triple A (AAA, Alianza Anticomunista Argentina).

\footnotetext{
${ }^{12}$ Nesse momento, a União Cívica Radical del Pueblo, facção mais conservadora da antiga UCR, havia retomado os direitos sobre o uso da sigla. Dessa maneira, Balbín concorreu no pleito pela UCR. Já a UCRI, dos intransigentes, formou um novo partido, o Partido Intransigente, que lançou como candidato Oscar Alende, quem obteve 7,5\% dos votos.
} 
Na EUDEBA, as transformações políticas propiciaram a troca de sua gerência. Em uma assembleia de acionistas realizada no dia 18 de junho de 1973, foram escolhidas as novas autoridades que assumiriam o controle da editora em 29 de junho do mesmo ano. Seu presidente passaria a ser o intelectual e jornalista Arturo Jauretche e o Gerente Geral (o nome oficial do cargo era "Diretor Executivo") seria o também jornalista Rogelio García Lupo. Ambos peronistas, ambos de esquerda. ${ }^{13}$ A "Primavera Camporista" chegava à EUDEBA.

A escolha de Arturo Jauretche e Rogelio García Lupo inseriu-se em um conjunto de mudanças feitas no Ministério da Educação e na UBA com a ascensão do governo peronista. O ministro escolhido para organizar a educação argentina foi Jorge Taiana, decano da Faculdade de Medicina da UBA e ex-reitor da universidade durante a segunda presidência de Perón (1952-1955). Cumprindo uma agenda que propugnava colocar a universidade "a serviço do povo", Taiana reincorporou diversos docentes que haviam sido afastados após os golpes de Estado de 1955 e 1966, ordenou o ingresso irrestrito de estudantes em todas as universidades públicas e incentivou essas instituições a adequarem seus programas às "necessidades nacionais" (RODRÍGUEZ, 2015, pp. 23-24).

Como reitor interventor da UBA foi nomeado o historiador Rodolfo Puiggrós, um ex-membro do Partido Comunista que se tornara peronista nos anos 1940 e atuava, quando de sua nomeação, como intelectual da esquerda peronista (RODRÍGUEZ, 2015, pp. 24-29). Em consonância com as ações de Taiana, Puiggrós teve como medidas de destaque a implantação de cursos introdutórios para os ingressantes (uma espécie de "ciclo básico"), a criação de novos centros de pesquisa, a alteração de diversos programas curriculares e o fim dos exames de ingresso, trabalhando em nome da criação do que entendia como uma universidade nacional e popular (FRIEDEMANN, 2014, pp. 89-90).

As tensões existentes na sociedade argentina não ficaram apartadas dos claustros universitários. A esquerda peronista efetuou ocupações em diversas universidades para

${ }^{13}$ Arturo Jauretche, inclusive, fora convidado de honra na posse do presidente Héctor Cámpora, assistindo à cerimônia de uma das sacadas da Casa Rosada. Para mais informações sobre Jauretche, ver GALASSO, 2014. 
reforçar suas posições de luta pela realização da "pátria socialista". No fim do ano de 1973, foram efetuadas eleições para definir os dirigentes dos centros estudantis. Durante a campanha das chapas, enfrentamentos violentos foram registrados em todo o país entre organizações de estudantes das direitas e das esquerdas. Na UBA, por exemplo, afirma Laura Rodríguez, "la JUP [esquerda peronista] denunció agresiones de parte de la Juventud de la Revolución Libertadora [direita não peronista]" (RODRÍGUEZ, 2015, pp. 23-35). O ministro Taiana não foi poupado de achaques e críticas. Após a vitória da JUP nas eleições para o centro de estudantes da UBA, o Conselho Superior do Justicialismo chamou-lhe para uma reunião com o objetivo de cobrá-lo por não ter agido para impedi-la - reunião à qual o ministro não compareceu. No mês de novembro de 1973, a revista Alianza Libertadora Nacionalista, ligada à direita peronista, afirmava que Taiana era "el 'ministro de la contrarrevolución" e assegurava que ele estava “' 'pésimamente rodeado' y que era un 'peligro', entre otras cosas porque había invitado al pedagogo brasileño Paulo Freire, ligado al gobierno 'marxista' de Allende en Chile" (RODRÍGUEZ, 2015, pp. 23-36).

Os novos tempos na EUDEBA foram marcados pela explicitação da penetração da política no cotidiano da editora e pelo acirramento das tensões internas - muitas das quais refletiram tensões da política nacional. Logo na primeira reunião do novo diretório, o presidente, Arturo Jauretche "manifiesta que se abre una nueva etapa para Eudeba, expresando que se debe hacer una gran Editorial Continental, como instrumento de contacto cultural y universitario con Latinoamérica". ${ }^{14}$

A reunião continuou, e um funcionário da EUDEBA, Jorge Schvarzer, tomou a palavra para afirmar que não havia problemas em relação aos trabalhadores da editora, uma vez que estes manifestaram que ofereceriam "toda su colaboración para hacer de Eudeba una Editorial al servicio de una cultura nacional y popular". ${ }^{15}$

O novo diretório deixava explícito, portanto, seu alinhamento ideológico com o projeto cultural da esquerda peronista, que enxergava a educação e a cultura como

\footnotetext{
${ }^{14}$ Ata de reunião do Diretório da EUDEBA n. 234, de 29 de junho de 1973. Consulta efetuada no arquivo da Editorial Universitaria de Buenos Aires.

${ }^{15}$ Ibidem.
} 
instrumentos de transformação popular. Reforçando tal elo, Arturo Jauretche acrescenta, em sua fala, o elemento "latino-americano" à missão da editora. ${ }^{16}$

$\mathrm{Na}$ mesma reunião, anuncia-se um concurso de ensaios sobre problemas nacionais a ser promovido pela editora, intitulado Prêmio Raúl Scalabrini Ortiz, que fora um intelectual nacionalista argentino. Junto a Jauretche, nos anos 1930, Scalabrini Ortiz construiu uma trajetória intelectual de defesa dos interesses nacionais em detrimento da penetração estrangeira, tornando-se um apoiador distante do peronismo nos anos 1940. Falecera em 1959 e suas obras tornaram-se referências para os intelectuais nacionalistas e peronistas dos anos 1970. O batismo do concurso com seu nome representa uma mudança nas práticas da editora. Na primeira etapa da EUDEBA, como vimos anteriormente, o concurso mais importante solicitou aos autores que enviassem ensaios sobre a Constituição. Transcorridos quase dez anos do certame, a comparação entre os concursos permite entrever que a crença exacerbada no império da lei não conseguiu resolver - ao menos para os peronistas de esquerda que ora comandam a editora - os problemas nacionais. Além disso, o apelo a Scalabrini Ortiz pode ser entendido, também, como uma maneira de mudar os referenciais teóricos que passaram a balizar, dali em diante, as ações editoriais da EUDEBA. Saem os “iluministas", entram aqueles preocupados com o campo nacional-popular.

Nas reuniões seguintes, o projeto editorial de Jauretche e García Lupo tornar-seia mais cristalino por meio das listas de livros aprovados para publicação. No dia 27 de julho de 1973, surge um plano de publicações encabeçado pela seguinte coleção:

1- América Latina Libre y Unida: - Héctor José Cámpora "La Revolución Peronista"; - Salvador Allende "La Revolución Chilena"; - Tenente General Juan Domingo Perón "La Revolución en América Latina"; - Osvaldo Articas "La Revolución Cubana". ${ }^{17}$

\footnotetext{
16 Outro indício de adesão ao projeto de uma universidade nacional e popular foi a mudança, nas atas do diretório, da nomenclatura da UBA (Universidad de Buenos Aires) para U.N.B.A. (Universidad Nacional de Buenos Aires), seguindo diretrizes adotadas pela reitoria de Puiggrós.

${ }^{17}$ Ata de reunião do Diretório da EUDEBA n ${ }^{\circ}$ 237, de 27 de julho de 1973. Consulta efetuada no arquivo da Editorial Universitaria de Buenos Aires.
} 
Também chama a atenção no plano a presença de dois livros de membros do diretório: Manuel Ugarte y la unidad de América Latina, de Norberto Galasso (Síndico Suplente), e Geopolitica de la liberación, do próprio presidente Arturo Jauretche.

Nota-se que a coleção América Latina Libre y Unida traz títulos que explicitam o alinhamento do diretório da EUDEBA com as ideias dos grupos da esquerda peronista. Os quatro títulos planejados contêm a palavra "revolução", e dois deles falam de processos históricos declaradamente socialistas (Cuba e Chile), cada um à sua maneira. Entretanto, é necessário ressaltar que o autor escolhido para tratar da revolução na Argentina (a "peronista") não é Perón, mas Cámpora. Em contrapartida, textos de Perón seriam compilados para formar o volume sobre uma pretensa revolução latinoamericana. Tal operação encaixa-se no contexto em que se situavam os grupos da esquerda peronista naquele momento histórico. Cada vez mais achacados pela ala direita do peronismo, buscavam voz própria para determinar os caminhos do governo justicialista. Acrescente-se a isso um detalhe: no dia em que a coleção apareceu no plano editorial, o governo de Cámpora já havia terminado, o que torna o livro uma espécie de obra póstuma sobre a "Primavera Camporista".

O plano editorial, entretanto, não é o único ponto conspícuo na reunião de diretório do dia 27 de julho de 1973. O primeiro ponto da pauta tratado pelo gerente Rogelio García Lupo intitulava-se "Problemas políticos de la empresa". Ao tratá-lo, García Lupo informava:

\begin{abstract}
a los Señores Directores de la situación externa de la Editorial manifestando que se han registrado diversas amenazas personales y el ataque a un taller de encuadernación donde se realizaban trabajos para Eudeba, que provocó el incendio de ejemplares que se encontraban en preparación, culminando con un llamado anónimo alertando sobre la existencia de explosivos en la Editorial. ${ }^{18}$
\end{abstract}

Uma notícia do jornal Folha de São Paulo, publicada no dia 26 de julho de 1973, com informações da agência de notícias Associated Press, oferecia mais detalhes sobre o ocorrido:

\footnotetext{
${ }^{18}$ Ata de reunião do Diretório da EUDEBA no 237, de 27 de julho de 1973. Consulta efetuada no arquivo da Editorial Universitaria de Buenos Aires. 


\begin{abstract}
Argentina: direita ataca. [...] Segunda-feira, indivíduos armados invadiram uma gráfica e queimaram uma edição de 30 mil exemplares do livro " $O$ Marxismo", do francês Henri Lefebvre. A obra havia sido impressa pela "Editorial Universitaria de Buenos Aires" (EUDEBA), dirigida por peronistas de esquerda. [...] $\mathrm{O}$ mais grave choque entre as facções rivais peronistas ocorreu no dia 20 de junho, nas proximidades do Aeroporto Internacional de Ezeiza, quando quase três milhões de pessoas se concentraram para a recepção a Perón, que retornava da Espanha. Elementos armados [...] ligados aos setores direitistas do peronismo abriram fogo contra colunas e jovens esquerdistas que haviam cercado o local. Houve mais de 30 mortos e 500 feridos. ${ }^{19}$
\end{abstract}

Em entrevista à pesquisadora Judith Gociol, Rogelio García Lupo afirmou que o grupo terrorista que atacou as oficinas de impressão não ateou fogo a exemplares de $E l$ Marxismo, de Henri Lefebvre, mas, por engano, queimou livros de outra editora que estavam em impressão na mesma gráfica. A obra de Lefebvre, uma reimpressão, teria sido editada e vendido muito bem (GOCIOL, 2012, p. 53). Deixando de lado essa particularidade, o episódio mostra com clareza a penetração nada implícita da violência social existente no país no cotidiano da editora. O diretório comandado por Arturo Jauretche deixara claro suas preferências ideológicas por meio dos títulos que planejava editar, e isso provocou retaliações, gerando medo entre os funcionários e diretores. A repercussão do ataque é grande e permite vislumbrar o grau elevado de polarização existente no país. Além disso, a notícia da Folha de São Paulo traz, em retrospecto, informações sobre a volta de Perón à Argentina. Desde o dia 20 de junho, portanto, o líder do justicialismo estava em território nacional, o que trouxe consequências que merecem uma análise detida.

A volta de Perón, como narra a notícia, provocou embates violentos entre setores da direita e da esquerda peronistas em um evento conhecido como Massacre de Ezeiza. Para recepcionar o líder, que voltaria definitivamente ao país após 17 anos de exílio, os peronistas organizaram uma grande manifestação popular. A maioria dos preparativos ficou nas mãos de José López Rega, provocando reações por parte da Juventude Peronista, que convocou milhões de pessoas para irem ao aeroporto e recepcionarem Perón. Era mais uma tentativa de se comunicar com o líder. Entretanto, setores da CGT e grupos paramilitares relacionados a López Rega atacaram os Montoneros e a

\footnotetext{
${ }^{19}$ Folha de São Paulo, 25 de julho de 1973. Consultado no Acervo Digital da Folha de São Paulo na internet.
} 
Juventude Peronista, com um saldo trágico. No dia seguinte, ao dar sua primeira declaração pública, Perón nada disse sobre o massacre e pediu que a ordem voltasse a reinar no país. Tal indiferença revoltou a juventude e os grupos pertencentes à esquerda peronista, que ainda teriam de suportar declarações em que Perón os chamava de "muchachada apresurada". Em contraposição, Perón passaria a negociar uma saída de compromisso com os setores do "velho" sindicalismo peronista. Tornava-se cada vez mais nítida sua guinada à direita, conforme avalia texto publicado em La Nación:

\begin{abstract}
Perón ha tomado partido a favor de una, entre las dos facciones en pugna, pero esto lo sabíamos, en realidad, desde su discurso de 21 de junio. [...] El caudillo justicialista profundizó hasta el límite políticamente permisible sus discrepancias con el ultraizquierdismo. En ese sentido, quienes quieran seguir imputando a una desviación de López Rega o de otras personas influyentes [...] los giros a los cuales se ha aplicado últimamente el movimiento, tendrán que realizar una proeza manifiesta. ${ }^{20}$
\end{abstract}

O pêndulo movimenta-se ainda mais à direita quando, em 12 de julho de 1973, Cámpora renuncia a seu mandato junto com seu vice, Solano Lima. A manobra foi certeira por parte de Perón e da direita peronista, uma vez que assumiu a presidência interina e convocou eleições o presidente da Câmara Raúl Lastiri - que era também genro de José López Rega. Em 23 de setembro, elegia-se, com 62\% dos votos, a chapa Juan Domingo Perón e Maria Estela Martínez de Perón, que tomou posse em 12 de outubro de 1973, dando início a um governo que tentaria acabar, prática e simbolicamente, com o que restava da "Primavera Camporista". A direita peronista estava oficialmente no poder.

Na UBA, o viés nacional e popular implantado pela gestão de Rodolfo Puiggrós propiciara, por exemplo, a criação de um curso chamado "Historia de las luchas sociales argentinas". A EUDEBA não ficou de fora dessa empreitada, uma vez que, em reunião do diretório realizada no dia 3 de agosto de 1973, Rogelio García Lupo afirma que a universidade solicitara à EUDEBA “la publicación de 50.000 ejemplares del texto que se utilizará en el curso sobre 'Historia de las luchas sociales argentinas', que se

\footnotetext{
${ }^{20}$ La Nación, 5 de agosto de 1973. Apud: GALASSO, Norberto. Jauretche: biografía de un argentino. Buenos Aires: Colihue, 2014, p. 297.
} 
dictará en todas las facultades". ${ }^{21}$ Dessa maneira, a UBA definia uma política educacional baseada na difusão de um conhecimento considerado essencial para a definição dos rumos nacionais. A informação de que o curso seria "dictado" (ministrado) em todas as faculdades reforça tal afirmação. A universidade era vista, nesse momento, como uma forma de transformação social da Argentina. O grupo de Puiggrós - com ideias afins às defendidas pelo grupo da EUDEBA - oferecia, dessa maneira, sua contribuição para um processo político - e histórico - que entendia como parte de uma mudança nacional importante. $\mathrm{O}$ momento era crítico e, nas palavras de Puiggrós,

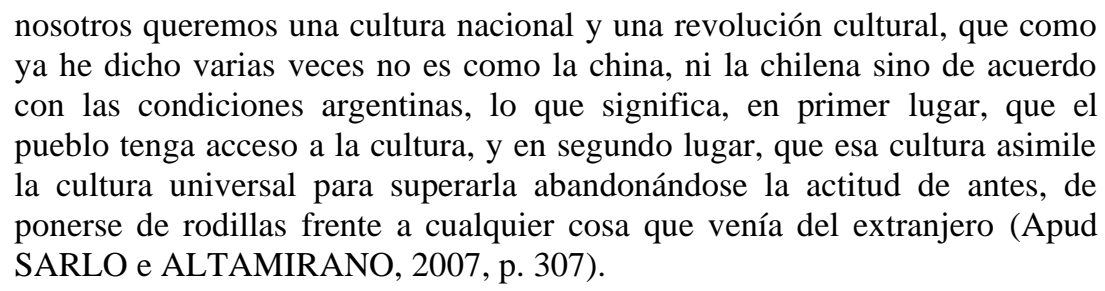

A cultura, aqui, é entendida como uma forma de alterar a postura de "ajoelhar-se perante o estrangeiro", criticada pelos intelectuais do campo do peronismo de esquerda. Na mesma fala, Puiggrós afirma, ainda:

algunos opinan que la incultura se ha adueñado de las Universidades, y que la Argentina al incorporarse al Tercer Mundo renuncia a su tradición cultural. Nosotros no renunciamos a nada, lo que pasa es que no queremos quedarnos en esa tradición cultural sino superarla (Apud SARLO e ALTAMIRANO, 2007, p. 307).

Com isso, o então reitor ratificava seu posicionamento e suas inclinações na gestão da universidade. É importante notar o contraponto com os pensamentos da gestão anterior da EUDEBA, capitaneada por Juan Pablo Oliver, que, como analisamos anteriormente, afirmou mais de uma vez que a EUDEBA deveria atuar em nome da cultura e das tradições argentinas. Ao alinhar-se ao "terceiro mundo", a UBA - e a

\footnotetext{
${ }^{21}$ Ata de reunião do Diretório da EUDEBA n. 238, de agosto de 1973. Consulta efetuada no arquivo da Editorial Universitaria de Buenos Aires.
} 
EUDEBA - colocava-se definitivamente no campo nacional e popular, posicionando-se à esquerda do movimento peronista.

A reação a tal posicionamento foi múltipla e veio por diferentes caminhos. $\mathrm{O}$ primeiro afetado foi o próprio Rodolfo Puiggrós. Por pressão dos setores da direita peronista, em outubro de 1973, o ministro da educação, Jorge Taiana, solicitou que ele renunciasse ao cargo, o que foi feito. Puiggrós estava sendo ameaçado pelas milícias da Triple A e seu nome apareceu na lista de condenados à morte da organização. Pouco tempo depois, exilou-se no México.

As tensões se avolumavam. Taiana nomeou Ernesto Villanueva como reitor da UBA. Este, por sua vez, declarou que seguiria a linha de gestão adotada por Puiggrós. Os estudantes ligados à esquerda peronista radicalizavam cada vez mais seu discurso. A relação de Perón com os peronistas de esquerda era ambígua ${ }^{22}$ e teve reflexos diretos na EUDEBA. Em uma reunião do diretório realizada no dia 30 de agosto de 1973 - poucas semanas antes, portanto, das eleições presidenciais - Rogelio García Lupo narra que o intelectual Jorge Abelardo Ramos tivera uma reunião com Perón para, em suas palavras:

\begin{abstract}
solicitarle su colaboración en esta nueva etapa de Eudeba. De tal conversación surge la posibilidad de hacer una entrevista grabada con el Gral. Perón para el libro "La Revolución Latinoamericana" que integraría la colección América Latina Libre y Unida. Asimismo el Gral. Perón adelantó al Sr. Ramos, que pondrá a su disposición la correspondencia secreta mantenida con Getulio Vargas y la documentación sobre la entrevista mantenida con el Gral. Carlos Ibañez. ${ }^{23}$
\end{abstract}

A ambiguidade prosseguiu. Em ata de reunião realizada no dia 16 de novembro de 1973, Rogelio García Lupo informa ao diretório que

va a firmarse con la Secretaría de Prensa de la Nación un contrato de edición de los discursos y obras del Gral. Juan Domingo Perón, y que con este motivo ha celebrado una reunión con el Secretario de Prensa de la Nación. ${ }^{24}$

\footnotetext{
22 Para uma análise aprofundada das ambiguidades de Perón em relação ao peronismo de esquerda, ver SIGAL e VERÓN, 2014.

${ }^{23}$ Ata de reunião do Diretório da EUDEBA n. 241, de 30 de agosto de 1973. Consulta efetuada no arquivo da Editorial Universitaria de Buenos Aires.

${ }^{24}$ Ata de reunião do Diretório da EUDEBA n. 251, de 16 de novembro de 1973. Consulta efetuada no arquivo da Editorial Universitaria de Buenos Aires.
} 
Não fica claro quem procurou quem para acertar a publicação das obras e discursos de Perón. Caso tenha sido o governo da Nação a procurar a EUDEBA, podese entender o movimento como mais um dos muitos acenos feitos por Perón e seu entorno à esquerda peronista. Caso tenha ocorrido o caminho inverso, o documento nos mostraria um empenho da EUDEBA, administrada pela esquerda peronista, em negociar com o já presidente eleito Juan Domingo Perón. Tal negociação poderia se dar com a expectativa de obter mais espaço no poder, mantendo influência sobre um governo que tendia cada vez mais para a direita. Ademais, não se pode ignorar a crise econômica pela qual passava a EUDEBA. Rogelio García Lupo sabia que a continuidade do projeto de uma editora nacional e popular passava pela ajuda monetária governamental (direta ou por meio da UBA), e a tentativa de negociação analisada poderia representar um aceno no sentido de obter facilidades financeiras. Seja como for, era um diálogo de surdos, o que fica evidenciado pelo desfecho das tratativas para a edição das obras de Perón, entrevisto nas palavras grafadas em uma ata de reunião do diretório da EUDEBA em 26 de julho de 1974:

\begin{abstract}
Eudeba editaria con mucho gusto las Obras Completas del General Perón si contara con un contrato de edición en regla, que debería ser firmado por la heredera legal del ex-presidente, Señora María Estela de Perón. [...] Recuerda el Director Ejecutivo [Rogelio García Lupo] que gestiones en este sentido se realizaron, en vida del General Perón, por lo menos tres: una ante el Secretario de Estado de Prensa y Difusión, señor Emilio Abras; otra por intermedio del Dr. Jorge Abelardo Ramos, ante el propio General Perón, y una tercera que estuvo a cargo del ex-rector normalizador Vicente Solano Lima. Ninguna de las tres condujo a la concreción del objetivo buscado. ${ }^{25}$
\end{abstract}

As palavras registradas na ata são elegantemente escolhidas, mas permitem entrever certa mágoa com Perón e seu entorno, que não permitiram a publicação, por parte da EUDEBA, de suas obras completas - mesmo após sua morte, ocorrida em $1^{\circ}$ de julho de 1974. Ao afirmar que as editaria "con mucho gusto" se tivesse um contrato com a herdeira - a então presidente do país María Estela de Perón -, transfere para o outro lado a responsabilidade pelo fracasso da empreitada. Da mesma forma, ao elencar, numerar e enfatizar as três tentativas de negociação, constrói uma gradação narrativa

\footnotetext{
${ }^{25}$ Ata de reunião do Diretório da EUDEBA n. 282, de 26 de julho de 1974. Consulta efetuada no arquivo da Editorial Universitaria de Buenos Aires.
} 
que culmina com a decepção de que nenhuma delas levou ao objetivo buscado. A última delas, ressalte-se, foi feita por meio do então reitor "normalizador" Vicente Solano Lima, que fora vice-presidente da Argentina durante o mandato de Héctor Cámpora e ocupava concomitantemente com a reitoria da UBA o cargo de secretário geral da presidência de Juan Domingo Perón. A EUDEBA falara, mas Perón, com seus acenos ambíguos, não ouvira - ou fingira não ouvir.

Na primeira reunião do diretório da EUDEBA do ano de 1974, chama a atenção a leitura de uma carta de renúncia redigida pelo então síndico da editora, Norberto Galasso. A transcrição do texto ocupa uma página inteira da ata. Galasso iniciou seu pedido de renúncia afirmando que, em meados de 1973, aceitara o convite de Arturo Jauretche com o intento de auxiliar no processo de reconstrução da editora. De acordo com ele:

El momento parecía óptimo para transformar a la Editorial en un poderoso instrumento al servicio de la cultura nacional que diese la batalla definitiva contra la superestructura cultural oligárquica y que, al mismo tiempo, difundiese los nuevos vientos revolucionarios que soplan por el mundo. ${ }^{26}$

A indicação de Norberto Galasso para exercer o cargo de síndico na EUDEBA teve múltiplas motivações. Além de ser contador formado pela Faculdade de Economia da UBA, já se destacava como escritor de livros em que analisava a biografia de personagens da história argentina associando-as às lutas sociais ocorridas no período histórico em que viveram. À época, destacavam-se entre suas publicações obras sobre o compositor Enrique Santos Discépolo e sobre o escritor ligado ao campo nacional popular Raúl Scalabrini Ortiz. Era amigo e parceiro intelectual de Arturo Jauretche e, como podemos notar no excerto anterior, partilhava com ele o intento de transformar o novo momento peronista na Argentina em uma experiência cultural revolucionária.

De acordo com a carta de renúncia de Galasso, o sucesso da nova fase da EUDEBA poderia ser assegurado devido ao "triunfo popular en las elecciones y el

\footnotetext{
${ }^{26}$ Ata de reunião do Diretório da EUDEBA n. 258, de 4 janeiro de 1974. Consulta efetuada no arquivo da Editorial Universitaria de Buenos Aires.
} 
fervoroso recebimiento de los trabajadores de Eudeba a la nueva conducción presidida por Usted [Arturo Jauretche]”. ${ }^{27}$ Entretanto, havia uma condição:

que la Editorial tuviese el apoyo financiero necesario para remontar el estado de agonía a que la habían llevado las anteriores administraciones. Ahora, después de un período de tiempo suficientemente largo para aventar toda duda, sabemos ya que Eudeba carece de ese apoyo. ${ }^{28}$

A falta de apoio financeiro é o mote escolhido por Galasso para centrar fogo na política do governo peronista em relação às universidades e à EUDEBA, como fica claro na sequência:

En julio de 1973 la Caja Nacional de Ahorro Postal le otorgó un crédito por doscientos cincuenta millones de pesos moneda nacional, pero desde esa fecha no ha podido utilizarse un solo peso, pues el Ministerio de Economía no ha otorgado la simple renovación de un aval de rutina, requisito indispensable para que el crédito pueda hacerse efectivo. La Reconstrucción Nacional no ha llegado para Eudeba. Ha llegado en cambio una política de destrucción. [...] Eudeba camina hacia el abismo ante la absoluta insensibilidad del Ministerio de Economía, directo responsable de este desastre. $^{29}$

A revolta de Galasso é política: ao dificultar o recebimento de empréstimos, o governo peronista atacara a editora em seu ponto mais delicado: a sustentabilidade financeira. Isso prejudicou a tarefa de que se incumbira e impediu o reerguimento da empresa e de seu projeto cultural. Para a equipe comandada por Arturo Jauretche, a reconstrução da EUDEBA era parte do processo de "reconstrução nacional" conduzido pelo peronismo no poder. ${ }^{30}$ Ao negar-lhe as condições para tanto, o banco nacional mencionado no texto negava-lhe também a participação em tal processo - e, consequentemente, no governo peronista.

Norberto Galasso finaliza sua carta de renúncia da seguinte maneira:

Probando una vez más que los trabajadores son la columna vertebral de la Revolución Nacional en marcha al Socialismo Nacional el personal de

\footnotetext{
${ }^{27}$ Ibidem.

${ }^{28}$ Ata de reunião do Diretório da EUDEBA n. 258, de 4 janeiro de 1974. Consulta efetuada no arquivo da Editorial Universitaria de Buenos Aires.

${ }^{29}$ Ata de reunião do Diretório da EUDEBA n. 258, de 04 janeiro de 1974. Consulta efetuada no arquivo da Editorial Universitária de Buenos Aires.

${ }^{30} \mathrm{O}$ nome do plano geral de governo de Héctor Cámpora, lançado em maio de 1973, foi “Programa de Reconstrucción y Liberación Nacional".
} 
Eudeba se ha movilizado recientemente contra esa política de destrucción. En la certeza de que esa protesta popular es el único medio para evitar el hundimiento de Eudeba, me sumo a ella presentando a Usted mi renuncia al cargo de Síndico. ${ }^{31}$

Dessa forma, Galasso marca uma posição clara: renuncia à participação institucional em um governo que não está cumprindo suas obrigações com o campo popular, mas não renuncia à luta política. Em lugar das funções oficiais, insere-se no conjunto de protestos populares dos trabalhadores da EUDEBA. Nesse ponto, a editora torna-se, no discurso do renunciante, homóloga ao governo peronista. Para evitar o naufrágio e o "hundimiento" do peronismo no poder, já em avançado processo de guinada à direita, Norberto Galasso posta-se à esquerda, defendendo o protagonismo dos trabalhadores na luta pela retomada do viés nacional e popular do peronismo. A direção, para a esquerda peronista, era a pátria socialista, presente na carta de Galasso. Entretanto, a cada dia ela ficava mais distante da pátria peronista construída pela ala direita do peronismo, grupo a que pertencia a maior parte dos que compunham o governo de Juan Domingo Perón.

Ao chegarmos aqui, é importante relembrarmos que a sustentação financeira da EUDEBA foi um dos assuntos mais discutidos ao longo de sua história e durante o período analisado permaneceu sendo um problema. Em 26 de julho de 1973 fora feito um pedido de empréstimo à Caja Nacional de Ahorro Postal, conforme lembrou Norberto Galasso em sua carta de renúncia. ${ }^{32}$ Entre o pedido de empréstimo e a renúncia de Galasso (4 de janeiro de 1974), a situação da EUDEBA se deteriorou visivelmente. Entre outros problemas registrados em ata, houve greve por parte de revisores que trabalhavam em regime autônomo (freelance) e reivindicavam o pagamento de uma dívida de honorários acumulada por um ano, ${ }^{33}$ além do anúncio de que a editora pararia de pagar os fornecedores para conseguir honrar seus compromissos

\footnotetext{
${ }^{31}$ Ata de reunião do Diretório da EUDEBA n. 258, de 04 janeiro de 1974. Consulta efetuada no arquivo da Editorial Universitária de Buenos Aires.

${ }^{32}$ Ata de reunião do Diretório da EUDEBA n. 236, de 26 de julho de 1974. Consulta efetuada no arquivo da Editorial Universitaria de Buenos Aires.

33 Ata de reunião do Diretório da EUDEBA n. 257, de 22 de dezembro de 1973. Consulta efetuada no arquivo da Editorial Universitaria de Buenos Aires.
} 
salariais com os trabalhadores internos. ${ }^{34}$ Enquanto isso, o empréstimo tramitava no Ministério da Economia e era postergado de diversas maneiras, incluindo demora anormal na assinatura de um aval para a concessão, imposição de obstáculos burocráticos ao pedido e adiamentos sucessivos. ${ }^{35}$ Galasso renunciaria e o empréstimo continuaria em suspenso.

O diretório da EUDEBA e seus trabalhadores resistiram por meio de diversas ações. Enquanto Rogelio García Lupo acionava suas redes de contatos para obter alguns subsídios emergenciais da UBA, os trabalhadores publicaram na imprensa um informe denunciando a situação e cobrando ações imediatas do governo. ${ }^{36}$ Algumas semanas depois, uma ata de reunião do diretório transcreve um telegrama enviado ao ministro da Economia, José Gelbard ${ }^{37}$ :

Reiteramos colacionado 12 noviembre relativo a demorar ese ministerio para decidir sobre aval requerido por Caja Nacional de Ahorro respecto de un crédito ya otorgado Eudeba. Su intervención personal resulta indispensable afin evitar crisis financiera de Eudeba y graves derivaciones laborales. Personal Eudeba hállase estado de alerta en defensa fuente de trabajo y pago regular sueldos y aguinaldo [bônus de Natal]. En nombre Directorio Eudeba manifestamos nuestra esperanza en que la buena disposición hacia Editorial Universitaria que el Señor Ministro nos expresara personalmente encontrará la manera de concretarse en el terreno administrativo. Arturo Jauretche Presidente. Rogelio García Lupo Director Ejecutivo. ${ }^{38}$

A primeira informação do texto refere-se a um telegrama anterior enviado ao ministro da Economia em 12 de novembro de 1973. Tal telegrama havia ficado sem resposta. Diante desse cenário, o diretório enviou nova comunicação ao Ministério

\footnotetext{
${ }^{34}$ Ata de reunião do Diretório da EUDEBA n. 252, de 23 de novembro de 1973. Consulta efetuada no arquivo da Editorial Universitaria de Buenos Aires.

35 Atas de reunião do Diretório da EUDEBA n. 241, 247, 250 e 255 datadas, respectivamente, de 30 de agosto, 19 de outubro, 09 de novembro e 17 de dezembro de 1973. Consulta efetuada no arquivo da Editorial Universitaria de Buenos Aires.

${ }^{36}$ Ata de reunião do Diretório da EUDEBA n. 251, de 16 de novembro de 1973. Consulta efetuada no arquivo da Editorial Universitaria de Buenos Aires.

37 José Gelbard havia militado no Partido Comunista durante sua juventude e fora ministro da Economia entre 25 de maio de 1973 e 21 de outubro de 1974, atuando, portanto, em todos os governos peronistas do período. Foi de seu ministério que partiram as principais determinações voltadas a equilibrar a economia argentina, como o congelamento de preços e o chamado "pacto social", uma espécie de acordo entre a CGT e o governo no sentido de acalmar as rebeliões sociais e diminuir as pressões por aumentos salariais enquanto a pujança econômica não fosse novamente alcançada. Sofreu críticas de vertentes da esquerda peronista.

${ }^{38}$ Ata de reunião do Diretório da EUDEBA n. 253, de 07 de dezembro de 1973. Consulta efetuada no arquivo da Editorial Universitaria de Buenos Aires. A escrita original da transcrição foi mantida.
} 
insistindo que Gelbard concedesse o aval para o empréstimo junto à Caja Nacional de Ahorro. O argumento para a solicitação mistura a utilização de uma retórica administrativa (pagar salários e manter a empresa funcionando) - que ajuda a situar o discurso dentro de certa ordem institucional - e um elemento de ameaça, que é a possibilidade de mobilização por parte dos trabalhadores em defesa de seus empregos e de seus salários - o que, supostamente, deveria ser caro a um governo de orientação peronista, especialmente em um momento em que a presidência do país era ocupada especificamente por Juan Domingo Perón.

Perón seria mencionado na mesma reunião. Os trabalhadores da EUDEBA haviam telegrafado diretamente a ele:

7-12-73. Presidente Nación Tte. General Juan Perón. [...] Ante demora del Ministerio de Economía para otorgar aval de rutina a crédito concedido por Caja Nacional de Ahorro y Seguro mes de Julio [...] solicitamos su intervención personal por peligrar fuente de trabajo con consiguiente perjuicio trabajadores de Eudeba. Creemos que en la hora de la reconstrucción Nacional resulta inadmisible destrucción empresa al servicio de la cultura del pueblo. [...] Comisión Interna Eudeba. ${ }^{39}$

A diferença entre os destinatários dos dois telegramas é significativa. Em vez de telegrafarem para o ministro da Economia reforçando o pedido feito pela direção da EUDEBA, os trabalhadores, organizados em sua comissão e, portanto, atuando de maneira autônoma, optaram por enviar sua mensagem diretamente ao presidente do país. Dessa forma, consideram-se interlocutores diretos de Perón, reivindicando assim o protagonismo nas decisões sobre os rumos de uma empresa "a serviço do povo" e que estaria, também, a serviço do país e da sempre mencionada tarefa de reconstrução nacional. O recado é direto: solicita-se a intervenção de Perón para evitar a inadmissível destruição da EUDEBA. Teria Perón ouvido?

Não podemos responder com exatidão, uma vez que não foram encontrados documentos que comprovem uma ação direta de Perón em relação à editora. Entretanto, podemos vislumbrar alguns indícios de resposta por meio da análise das atas de reunião posteriores. Os adiamentos do empréstimo se prolongaram. Arturo Jauretche, que trabalhara ativamente pela obtenção do empréstimo, não pôde saber o desfecho da

\footnotetext{
39 Ata de reunião do Diretório da EUDEBA n. 253, de 07 de dezembro de 1973. Consulta efetuada no arquivo da Editorial Universitaria de Buenos Aires. A escrita original da transcrição foi mantida.
} 
história: em 25 de maio de 1974, faleceu na cidade de Buenos Aires aos 73 anos. O diretório da EUDEBA, em ata, transcreveu uma nota oficial da editora em que endossava sua luta pela "soberania nacional" em nome dos trabalhadores, acrescentando que Jauretche tentara "construir la universidad de todos los argentinos en una patria liberada". ${ }^{40} \mathrm{O}$ empréstimo, apesar de sinalizações favoráveis aqui e ali dentro do Ministério da Economia, não foi autorizado enquanto a EUDEBA esteve sob o comando de peronistas de esquerda. A universidade de "todos los argentinos" sonhada por Jauretche distanciava-se daquela projetada pelos peronistas que ocupavam o poder político no país.

Conforme observamos anteriormente, a primeira reunião de diretório comandada por Arturo Jauretche decidira realizar o concurso cultural Raúl Scalabrini Ortiz para selecionar, premiar e publicar os melhores trabalhos escritos sobre a realidade argentina e seus problemas. No dia 8 de fevereiro de 1974, o diretório definiu os vencedores do certame, aumentando para 30.000 pesos $^{41}$ o montante total a ser dividido entre os autores das seguintes obras: La dominación imperialista en Argentina, de Carlos María Vilas, Dependencia y empresas multinacionales, de Salvador María Lozada, e Neocapitalismo y comunicación de masas, de Heriberto Muraro. Além disso, a ata faz uma "recomendación" de outras obras que participaram do concurso: Inversiones extranjeras y dependencia, de Naum Minsburg, Los largos dedos de Bunge y Born, de Antonio Elio Brailovsky, El desarrollo desigual entre las dos Américas, de Abraham Guillén, Orígenes de la dependencia económica argentina, de Elena Bonura, La penetración económica extranjera en nuestra economía, de Orcar Orsolini, Hugo Constantini, Jorge Caminiti, Hector Brizuela, Oscar Liberman e Luis Gallegos e La Ley olvidada y un contrato colonial, de Juan Franco Doglioli e J. C. Dido. ${ }^{42}$ Assim, das dezesseis obras inscritas no concurso, apenas sete não receberam nenhuma menção ou prêmio, a saber: Soberanía y socialismo, La rebelión de las hijas, La transformación cultural como base de la consolidación de la Independencia, Monopolios: vida, pasión

\footnotetext{
40 Ata de reunião do Diretório da EUDEBA n. 273, de 31 de maio de 1974. Consulta efetuada no arquivo da Editorial Universitaria de Buenos Aires.

${ }^{41}$ Originalmente, o valor do prêmio era de 20.000 pesos.

42 Ata de reunião do Diretório da EUDEBA n. 261, de 23 de fevereiro de 1974. Consulta efetuada no arquivo da Editorial Universitaria de Buenos Aires.
} 
y...¿muerte?, La trilogía filosófica y su aplicación práctica en la destrucción monopólica por transformación social, económica y política, Un modelo de sistema para la lucha anti-imperialista e Racismo a la Argentina. ${ }^{43}$

O concurso foi divulgado pelo diretório de Jauretche como a maneira "más apropiada de proponer un método de trabajo para los intelectuales comprometidos con su país y con su época" (ZAROWSKY, 2016). Os avaliadores foram Arturo Jauretche, Rodolfo Puiggrós - já afastado de suas funções como reitor da UBA e perseguido pela direita peronista -, Arturo Sampay, Ernesto Villanueva - então reitor da UBA - e Rogelio García Lupo.

A análise superficial dos títulos participantes do concurso permite identificar um traço comum a todos: o pertencimento ao espectro ideológico do peronismo de esquerda. Temas caros aos intelectuais dessa vertente, tais como dependência, imperialismo e libertação nacional perpassam a maior parte dos livros que concorreram ao prêmio, privilegiando um quadro de análise da realidade argentina que trabalha, resumidamente, com uma análise crítica do poderio capitalista do primeiro mundo sobre os países periféricos, propugnando pela libertação por meio da ação popular nacionalista nos países do terceiro mundo - no caso da Argentina, o peronismo. Uma breve análise do arcabouço intelectual de uma das obras vencedoras do concurso - bem como da trajetória intelectual de seu autor - pode ajudar a elucidar melhor tais questões.

Heriberto Muraro, autor do livro Neocapitalismo y comunicación de masas, era, em 1974, um jovem sociólogo que começara sua inserção nos ambientes intelectuais em 1971 por meio da publicação de El poder de los medios de comunicación de masas, primeiro título da coleção Transformaciones, editada pelo Centro Editor da América Latina (CEAL). ${ }^{44}$ Em 1973, por meio da construção de uma rede de contatos nos campos político e intelectual, passou a colaborar com a revista Crisis, dirigida por

\footnotetext{
${ }^{43}$ Ata de reunião do Diretório da EUDEBA n. 261, de 23 de fevereiro de 1974. Consulta efetuada no arquivo da Editorial Universitaria de Buenos Aires. Dos autores que não foram mencionados na premiação, não sabemos os nomes, uma vez que a entrega dos trabalhos era feita sob pseudônimo e só foi registrada em ata a abertura dos envelopes com os nomes "reais" dos autores que receberam os prêmios e as menções de recomendação.

${ }^{44}$ O CEAL foi uma importante editora argentina criada em 1966 por José Boris Spivacow e outros intelectuais e trabalhadores que com ele renunciaram a seus cargos na EUDEBA quando do golpe de Estado perpetrado por Juan Carlos Onganía. Sobre o CEAL, ver BUENO e TARONCHER, 2006; GOCIOL, 2017; GOCIOL (et alli), 2008; ROMERO, 2012.
} 
Eduardo Galeano, e fez parte do grupo de professores que levou adiante o projeto de "reconstrução" da UBA sob a gestão de Rodolfo Puiggrós. Essa montagem de uma intrincada rede de contatos nos meios da esquerda peronista permitiu que recebesse um convite do próprio gerente da editora, Rogelio García Lupo, para participar do concurso.

O estudioso Mariano Zarowsky avalia que, junto à participação em Crisis e à publicação pelo CEAL, a vitória no concurso Raúl Scalabrini Ortiz propiciou a Muraro maiores possibilidades de difusão e recepção de sua obra nos meios intelectuais. A EUDEBA operou, assim, como instrumento de legitimação dentro do campo intelectual, reforçando o seu prestígio e a posição importante que detinha como veículo de transmissão cultural e espaço de atuação política.

Além disso, pode-se pensar de maneira mais ampla nas relações entre a premiação do concurso e o contexto histórico em que estava imersa a Argentina. Em fevereiro de 1974, momento em que foram anunciados os vencedores, a guinada à direita do governo peronista já estava mais que pronunciada. As forças paramilitares de José López Rega atuavam sub-repticiamente e a perseguição à esquerda peronista era cada vez mais forte. Oferecer uma premiação tão vultosa a obras de caráter abertamente alinhado ao pensamento de esquerda - ainda que fosse uma esquerda peronista - era, à época, algo muito perigoso, posto que explicitava uma postura política cada vez mais rechaçada pelo governo e suas forças paralelas.

Um dos indícios mais fortes a atestar a penetração das fissuras do tecido social da Argentina no cotidiano da EUDEBA é a relação entre a gestão de Arturo Jauretche e Rogelio García Lupo e o corpo de trabalhadores da editora. Inicialmente, a relação pautou-se em uma dinâmica de apoio, atestado, por exemplo, pela declaração, analisada anteriormente, de que os trabalhadores estariam engajados no projeto de transformar a EUDEBA em uma editora nacional e popular ${ }^{45}$. Ao analisarmos a correspondência particular do Diretor Executivo Rogelio García Lupo, outros elementos podem ser adicionados a esse apoio.

García Lupo era um jornalista e escritor altamente influente nos meios intelectuais de esquerda. Havia trabalhado em órgãos de imprensa argentinos e cubanos

\footnotetext{
${ }^{45}$ Ata de reunião do Diretório da EUDEBA n. 234, de 29 de junho de 1973. Consulta efetuada no arquivo da Editorial Universitaria de Buenos Aires.
} 
e possuía um círculo de relações que incluía destacadas figuras, como Eduardo Galeano e Ricardo Rojo, advogado que possuía acesso a Juan Domingo Perón durante seu exílio europeu, como se pode depreender de uma carta por ele escrita a García Lupo em $1^{\circ}$ de outubro de 1969. Na carta, após comentar sobre as movimentações estudantis e operárias que ocorriam na Argentina durante aquele ano - era o período pós-Cordobazo e a luta social no país estava em ebulição -, emenda: "En Madrid nos vimos con el Viejo: acuerdo general, pero en base a acciones concretas. Reitero, que JDP. me expresó su apoyo a Ongaro, aunque le critica no haber integrado los 20. De todas maneras, su posición general es promisoria". ${ }^{46} \mathrm{O}$ curto trecho mostra um dos fortes elos da rede de contatos de García Lupo, além de permitir vislumbrar uma das maneiras pelas quais as diretrizes de Perón no exílio chegavam à Argentina. Além de seus correspondentes autorizados, como John William Cooke, o líder do movimento utilizava de vozes auxiliares que transmitiam suas opiniões e posições - por vezes contraditórias - para os argentinos.

Assim, dado o prestígio e a trajetória de Rogelio García Lupo, os trabalhadores da EUDEBA alinhados ao peronismo concederam a ele, como admitiriam depois, uma "carta branca". ${ }^{47}$ Entretanto, as divisões ideológicas que marcavam o país e o peronismo também estavam presentes na editora e atingiram em cheio o novo diretor. Em 15 de julho de 1973, foi enviada a Rogelio García Lupo uma carta sem o nome do remetente. O objetivo de sua missiva era garantir a reversão de mudanças no organograma da empresa que, de acordo com sua interpretação, afetá-lo-iam - e a seus três "protegidos" - e consistiriam, assim, em uma retaliação política ao fato de não concordarem com a linha ideológica do atual diretório. Após a reivindicação, a carta muda bruscamente de tom. O autor afirma que não gostaria de usar sua influência para obter o que almeja. Prossegue informando que está trabalhando na Secretaría de Prensa de La Nación -

\footnotetext{
${ }^{46}$ Carta de Ricardo Rojo a Rogelio García Lupo, $1^{\circ}$ de outubro de 1969. Consulta efetuada no fundo Rogelio García Lupo do Arquivo da Biblioteca Nacional da República Argentina. O trecho se refere a Raimundo Ongaro, líder sindical fundador da CGT de Los Argentinos, braço combativo e radical do sindicalismo peronista. A fala é mais um exemplo dos acenos ambíguos de Perón, uma vez que, apesar de defender um acordo geral a fim de permitir a estabilização da situação política na Argentina, declara apoiar um setor sindical - o de Ongaro - ligado à esquerda peronista - Ongaro e seus seguidores foram, diversas vezes, acusados de serem "trotskistas".

${ }^{47}$ Comunicado "De un grupo de compañeros", de 1974. Consulta efetuada no fundo Rogelio García Lupo do Arquivo da Biblioteca Nacional da República Argentina.
} 
naquele momento um órgão subordinado ao presidente interino Raúl Lastiri, então genro do mais importante representante do peronismo de direita, José Lopéz Rega - e que "así como la izquierda insiste a través del ERP [Ejército Revolucionario del Pueblo] en su concepto de guerra total [...] así estoy también hoy, dispuesto a emplear todos los medios para defender mis compañeros de trabajo". ${ }^{48}$ Termina em uma chave ainda mais ameaçadora:

Esta es la primera y única gestión que hago para tratar de entendernos. Si no tuviera éxito en ello, rememorando las palabras de alguien que fuera inspirador en mis años mozos de mis ideas políticas maduras de hoy, te digo: "cuando se acaba la dialéctica de las palabras, comienza la dialéctica de las pistolas y de las balas". [...] Llega un momento en que uno sólo a través de la violencia puede sentirse liberado. ${ }^{49}$

Pelos dados que temos até o momento, poderíamos definir o remetente desconhecido como sendo um defensor de ideologias de direita e anticomunistas. Contudo, podemos ir além. Em determinado momento da carta, ele alude ao fato de que já conhecia Rogelio García Lupo desde 1956, quando haveriam lutado "juntos frente al gorilaje antinacional y destructivo encarnado por Aramburu (...)" ${ }^{50}$ A utilização de termos como gorilaje ${ }^{51}$ e antinacional para referir-se ao contexto político vigente em 1956 - momento em que Pedro Eugenio Aramburu comandou o governo provisório instaurado após a Revolução Libertadora, que depôs Juan Domingo Perón em 1955 permite que encaixemos nosso remetente dentro de uma posição política alinhada a um nacionalismo de direita muito similar ao que defendiam, à época, setores do peronismo de direita. Era esse personagem que ameaçava o diretor Rogelio García Lupo com uma paráfrase malfeita de um discurso proferido pelo criador do movimento fascista

\footnotetext{
48 Carta de funcionário não identificado da EUDEBA a Rogelio García Lupo, 15 de julho de 1973. Consulta efetuada no fundo Rogelio García Lupo do Arquivo da Biblioteca Nacional da República Argentina.

${ }^{49}$ Idem, ibidem.

50 Carta de funcionário não identificado da EUDEBA a Rogelio García Lupo, 15 de julho de 1973. Consulta efetuada no fundo Rogelio García Lupo do Arquivo da Biblioteca Nacional da República Argentina.

51 Gorilas, dentro do movimento peronista, era um termo utilizado para caracterizar aqueles que defendiam posições violentas e autoritárias.
} 
espanhol Falange, José Antonio Primo de Rivera. ${ }^{52}$ Ao decretar a possibilidade do fim da dialética das palavras, o remetente desconhecido anunciava de maneira sombria o tenso roteiro que seria vivenciado por García Lupo e Jauretche na condução da EUDEBA.

A política não ficaria de fora nem dos cumprimentos de fim de ano, o que é reforçado pela análise imagética de dois dos cartões enviados a García Lupo:

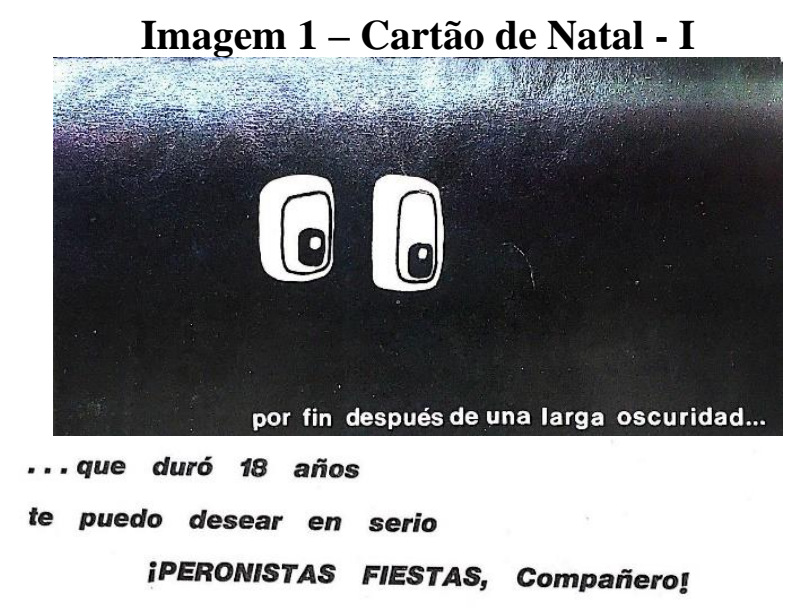

Fonte: Fundo Rogelio García Lupo, Biblioteca Nacional. ${ }^{53}$

52 O discurso original foi proferido por José Antonio Primo de Rivera em 29 de outubro de 1933, no ato de fundação da organização de inspiração fascista e totalitária Falange Española: "Bien está, sí, la dialéctica como primer instrumento de comunicación. Pero no hay más dialéctica admisible que la dialéctica de los puños y de las pistolas cuando se ofende a la justicia o a la Patria". Consultado em Biblioteca Nacional de España. Disponível em: 〈http://bdh.bne.es/bnesearch/detalle/bdh0000203092〉. Acesso em 26 de janeiro de 2020.

${ }^{53}$ Consulta efetuada no fundo Rogelio García Lupo do Arquivo da Biblioteca Nacional da República Argentina. 

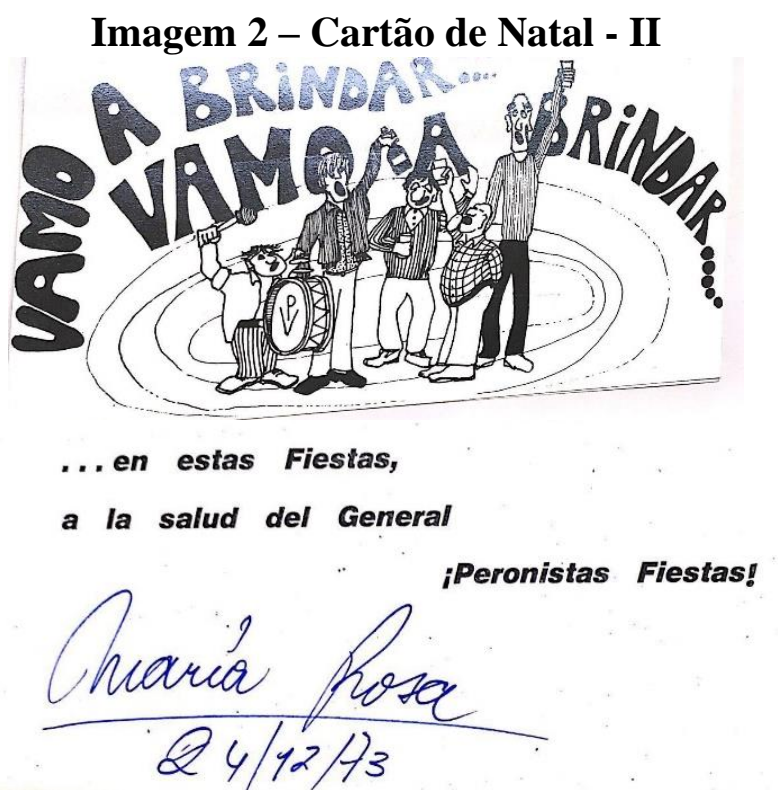

Fonte: Fundo Rogelio García Lupo, Biblioteca Nacional. ${ }^{54}$

Os cartões apresentam uma estética similar: na parte externa, um desenho entremeado por uma frase que termina em reticências; na parte interna, a continuação das frases e os desejos de boas festas. Seriam simples cartões de fim de ano, não fosse o conteúdo que carregam. Em vez de "boas festas", expressam o desejo de "peronistas fiestas". No primeiro deles, assinado pela "Flia. [Família] Fossati", do trabalhador da editora Eduardo Fossati, pode-se ver a contraposição entre a parte externa, que expressa o medo sentido durante um período de "larga oscuridad", e a parte interna, na qual se descobre que o medo havia sido provocado pelos "18 años" de ausência de Juan Domingo Perón da Argentina. Como tal ausência não mais existia, boas - e peronistas festas podiam ser desejadas.

No segundo cartão, as partes interna e externa não apresentam uma oposição semântica, mas complementam-se em sentido de triunfo. O brinde proposto em linguagem coloquial ("vamo a brindar") tem seu sentido festivo completo quando se descobre o que o motiva ("la salud del General"). No bumbo tocado por um dos personagens do desenho da parte externa do cartão, estão presentes as letras "PV", que

\footnotetext{
${ }^{54}$ Idem.
} 
permitem inferir que o cartão foi produzido por membros do peronismo de esquerda. Isso porque tais letras, transformadas em símbolo, foram largamente utilizadas nos cartazes produzidos pela juventude peronista na campanha eleitoral de Héctor Cámpora, em 1973. O "V", que, em contexto eleitoral significaria um chamado ao voto e uma insígnia de vitória, passou a representar, de acordo com Camilla Fontes de Souza, "a evocação política 'Perón Vuelve' e a sigla PV representava sua contração. Esta sigla ainda carregava um simbolismo importante daquele momento, compondo uma síntese gráfica onde se unem o líder justicialista e a juventude de seu partido" (SOUZA, 2013, p. 49). O apoio de alguns membros da esquerda peronista que atuavam na EUDEBA não garantiria, contudo, a esperada tranquilidade para a gestão de Rogelio García Lupo.

O ano de 1974 apresenta o transbordamento definitivo das tensões. Já em fevereiro, na terceira reunião do diretório no ano, García Lupo alerta sobre a publicação, na revista Militancia peronista para la liberación, de um anúncio da EUDEBA tratando da visita do chefe de Estado do Panamá à Argentina, General Omar Torrijos - a EUDEBA havia publicado um livro de sua lavra na coleção América Latina Libre y Unida. Na ata da reunião, registra-se:

El Director Ejecutivo, Sr. García Lupo, hizo notar que la publicación corría por exclusiva cuenta de la revista que lo había publicado, puesto que no se le había enviado orden ni copia del original ni tampoco ninguna clase de indicación que justificara la publicación. En vista de la irregularidad de la publicación, se decidió comunicar el hecho a la Universidad Nacional de Buenos Aires, con el propósito de evitar cualquier malentendido. ${ }^{55}$

Para entender melhor os motivos de tantas justificativas e alarmes na fala de García Lupo, vejamos o anúncio, que ocupava o terço inferior da página 29 da publicação:

\footnotetext{
55 Ata de reunião do Diretório da EUDEBA n. 260, de $1^{\text {o }}$ de fevereiro de 1974. Consulta efetuada no arquivo da Editorial Universitaria de Buenos Aires. 


\section{Imagem 3 - Anúncio General Torrijos}

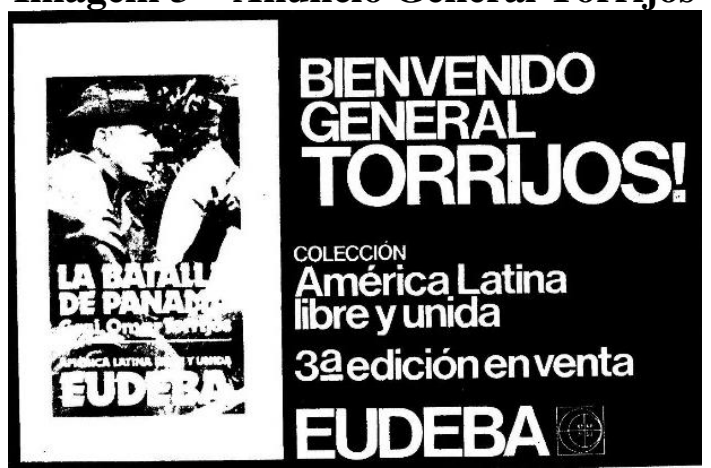

Fonte: Revista Militancia peronista para la liberación. ${ }^{56}$

Todos os elementos do anúncio coincidem com aqueles presentes em outros anúncios "oficiais" da EUDEBA publicados em periódicos da época, incluídos aqueles presentes nos arquivos de Rogelio García Lupo. Entretanto, a EUDEBA já vinha sofrendo acusações de ser esquerdista e, como vimos anteriormente, entre o lançamento da coleção América Latina Libre y Unida e o momento em que o anúncio foi realizado - início de 1974 -, muitas coisas haviam mudado no cenário político da Argentina.

Os recuos estratégicos no radicalismo político de Arturo Jauretche e Rogelio García Lupo - como o veemente rechaço à publicação do anúncio de boas-vindas ao general Omar Torrijos - não passaram em branco por aqueles que trabalhavam na EUDEBA. Em um comunicado interno não datado, mas que podemos localizar no ano de $1974,{ }^{57}$ membros dos trabalhadores, sob o pseudônimo de "Un grupo de compañeros", criticavam a falta de empenho entre os funcionários para lutar por seus direitos. O documento prossegue realizando uma espécie de mea culpa ao dizer que, devido à empolgação inicial propiciada pela vitória de Cámpora em 1973, entregaram a já aludida "carta branca" à nova administração da EUDEBA, sem perceberem que seria importante não se comprometerem com "los de arriba", fossem quem fossem. Expressaram decepção com as hierarquias mantidas por Jauretche e García Lupo,

56 Militancia peronista para la liberación, 17 de janeiro de 1974, p. 29. Disponível em: <http://www.ruinasdigitales.com/militanciaperonista/militancia-peronista-numero-31/>. Acesso em $25 \mathrm{de}$ janeiro de 2020.

${ }^{56}$ Consulta efetuada no fundo Rogelio García Lupo do Arquivo da Biblioteca Nacional da República Argentina.

${ }^{57}$ Há no texto uma menção ao trabalho realizado por funcionárias da Contaduría no mês de janeiro para fechar o balanço financeiro - o único mês de janeiro sob a administração de García Lupo ocorreu em 1974. 
demonstrando assim que desejavam ter participação ativa nos rumos da editora com a nova fase do governo nacional. Era a empolgação política da primavera camporista que atingira, também, os trabalhadores da EUDEBA. Entretanto, García Lupo nunca garantira nada a eles, que, "en cambio, por varios meses, nos atamos a su política, que no era la nuestra, según descubrimos después". 58

No mesmo comunicado, os trabalhadores expressaram seu descontentamento com a política editorial do diretório, considerada aquém do que esperavam para a ocorrência efetiva da "liberación nacional". Dessa maneira, afirmavam:

Otro tanto ocurrió con los intentos de esbozar una política editorial nacional y popular [...]. Siempre chocamos con un no. Creemos que estas frustraciones - más allá del problema financiero y el manejo elitista del Director Ejecutivo - fueron la consecuencia lógica de lo que estaba sucediendo en el país, pues Eudeba no es una isla. ${ }^{59}$

A mesma política editorial que publicara a coleção América Latina Libre y Unida agora era acusada de ser elitista, o que pode ser entendido como uma amostra do acelerado processo de desgaste das relações entre os trabalhadores da EUDEBA e o diretório comandado pela esquerda peronista. Ampliando o horizonte da análise, tal como faz brevemente o comunicado dos trabalhadores, o aumento das tensões internas pode ser entendido também como o respingo - ou a enxurrada - do caudal de transformações políticas da Argentina ao longo da segunda experiência peronista. Diante da impossibilidade de habitar e trabalhar em uma ilha, restava aos trabalhadores, bem como aos membros do diretório comandado por García Lupo, lutar por seus interesses.

Outro indício presente no documento dos trabalhadores que permite traçarmos um paralelo entre a política nacional e as tensões internas da EUDEBA é a questão relativa à cogestão. Na primeira reunião do novo diretório instituiu-se, em comum acordo, que, enquanto não fosse alterado o estatuto da editora para incluir oficialmente os trabalhadores no diretório, estes poderiam participar das reuniões como assistentes, com direito a voz, mas sem direito a voto. O compromisso da gestão de Jauretche e

${ }^{58}$ Comunicado de Un grupo de compañeros, 1974. Consulta efetuada no fundo Rogelio García Lupo do Arquivo da Biblioteca Nacional da República Argentina.

${ }^{59}$ Idem, ibidem, grifo nosso. 
García Lupo estava firmado: incluir os trabalhadores na administração da editora, tornando-os parte do diretório - o que implicava remunerações e atribuições oficiais, além do poder de fazer parte das decisões. Dessa maneira, encampava uma proposta que implantaria uma democracia quase direta na EUDEBA, algo que não ocorrera antes e não é praxe nas empresas - tanto públicas quanto privadas. Entretanto, a discussão foi adiada nas assembleias seguintes, e a gestão da esquerda peronista na EUDEBA terminou sem implantar a cogestão. Os autores do comunicado assim refletiram sobre a situação:

Los largos meses que pasamos tratando de obtener una participación efectiva en la dirección de la empresa - la ya legendaria cogestión - fueron desgastadores [...]. Logramos sí acceder a reuniones de Directorio. Pero nuestra presencia allí, efectivizada según las leyes, no pudimos obtenerla, siempre surgió algún inconveniente. $\mathrm{Y}$ al fin nos ganaron por cansancio. [...] Fue lógico seguir insistiendo con la cogestión después del 20 de junio y el 13 de julio? ${ }^{60}$

Como se nota, a cogestão é tratada com a ironia de quem desejou vê-la implantada como política de transformação institucional e nacional. Isso é evidenciado pela associação feita entre o fracasso interno da proposta e as emblemáticas datas de 20 de junho - dia do Massacre de Ezeiza - e 13 de julho - dia em que Héctor Cámpora renunciou ao poder.

Por fim, o comunicado dos trabalhadores, antes de clamar para que os compañeros fossem à luta para defender seus ideais, dispara contra Rogelio García Lupo e Arturo Jauretche, afirmando que o cansaço dos funcionários da editora teve seu apogeu quando compreenderam que "García Lupo y Jauretche eran una cosa en los libros y otra cosa en la editorial" e que "la 'EUDEBA popular y montonera' se moría de hambre muy cerca del millonario obelisco de la Argentina Potencia", ${ }^{61}$

O choque de viver um processo histórico no qual ocorreu uma "precipitación del tiempo histórico y de los acontecimientos", nas palavras de Oscar Terán, foi a marca central do período de gestão da esquerda peronista na EUDEBA (TERÁN, 2015, p. 291). Pudemos observar isso por meio de diversas vozes, em diversos tons e de diversas

${ }^{60}$ Comunicado de Un grupo de compañeros, 1974. Consulta efetuada no fundo Rogelio García Lupo do Arquivo da Biblioteca Nacional da República Argentina.

${ }^{61}$ Idem, ibidem. 
maneiras. A EUDEBA estava longe de ser uma ilha, de fato. Encerraremos nossa análise com uma carta de Rogelio García Lupo a Luis Carlos Ibañez, funcionário da editora Ediciones Tercer Mundo, da Colômbia. No trecho selecionado, chama a atenção a mistura entre a angústia e a pitada de humor irônico com que García Lupo analisa sua arriscada situação profissional em setembro de 1974:

\begin{abstract}
Estimado Ibañez: Si Ud. Se sumergió en los problemas del oficio, yo estoy sumergido en los líos de la Universidad Argentina, ahora en un plano inclinado realmente peligroso, porque el campo de batalla de la izquierda y la derecha peronista se ha consagrado como un campo sobre todo universitario. En estas condiciones, podrá imaginar lo inconfortable que resulta la dirección de una empresa que pertenece a la universidad. ${ }^{62}$
\end{abstract}

\title{
Referências bibliográficas
}

ALTAMIRANO, Carlos. Bajo el signo de las masas (1943-1973). Buenos Aires: Ariel, 2001.

ALTAMIRANO, Carlos. Peronismo y cultura de izquierda. Siglo XXI, 2013.

ÁLVAREZ, Gonzalo, ARCHAIN, Alejandro e DÍAZ, Carlos. Un editor de tres siglos: la vida y los libros de Arnaldo Orfila Reynal. Buenos Aires: EUDEBA, 2015.

BUENO, Mónica; TARONCHER, Miguel Ángel (orgs.). Centro Editor de América Latina: capítulos para una história. Buenos Aires: Siglo XXI, 2006.

CHARTIER, Roger. A História Cultural entre práticas e representações. Lisboa: Difel, 1990.

CARASSAI, Sebastián. Los años setenta de la gente común. Buenos Aires: Siglo XXI, 2015.

DE DIEGO, José Luis. Editores y políticas editoriales en Argentina, 1880-2000. Buenos Aires: Fondo de Cultura Económica, 2006.

FRIEDEMANN, Sergio. El marxismo peronista de Rodolfo Puiggrós: una aproximación a la izquierda nacional. Buenos Aires: Instituto de Investigaciones Gino Germani (Documentos de Jóvenes Investigadores n. 39), 2014, pp. 89-90. Disponível em: <http://webiigg.sociales.uba.ar/iigg/textos/documentos/dji39.pdf>. Acesso em 10 de janeiro de 2020.

GALASSO, Norberto. Jauretche: biografía de un argentino. Buenos Aires: Colihue, 2014.

\footnotetext{
62 Carta de Rogelio García Lupo a Luis Carlos Ibañez, de 3 de setembro de 1974. Consulta efetuada no fundo Rogelio García Lupo do Arquivo da Biblioteca Nacional da República Argentina.
} 
GARULLI, Liliana et alli (org.). Documentos de historia argentina (1955-1976). Buenos Aires: Eudeba, 2011.

GOCIOL, Judith. Boris Spivacow: el señor editor de América Latina. Buenos Aires: Capital Intelectual, 2010.

GOCIOL, Judith. Centro Editor de América Latina: una fábrica de cultura. Buenos Aires: Biblioteca Nacional, 2017.

GOCIOL, Judith. Libros para todos: colecciones de EUDEBA bajo la gestión de Boris Spivacow (1958-1966). Buenos Aires: Biblioteca Nacional, 2012.

GOCIOL, Judith; BITESNIK, Esteban; ETCHEMAITE, Fabiola; ETCHEMAITE, Mariano. Más libros para más: colecciones del Centro Editor de América Latina. Buenos Aires: Biblioteca Nacional de la Argentina, 2008.

GONZÁLEZ, Juan Ignacio. Estudantes e política sob ditadura: os universitários nas vésperas do Cordobazo (Córdoba, 1966-1969), apresentada ao Instituto de História da Universidade Federal Fluminense no ano de 2018. Disponível em: <https://www.historia.uff.br/stricto/tesesonline.php>. Acesso em: $20 \mathrm{de}$ fevereiro de 2020.

IZAGUIRRE, Inés. Lucha de clases, guerra civil y genocidio en argentina - 19731983. Buenos Aires: Eudeba, 2009

JAMES, Daniel (org.). Nueva Historia Argentina - violencia, proscripción y autoritarismo (1955-1976). Buenos Aires: Sudamericana, 2007.

JAMES, Daniel (org.). Resistencia e integración: el peronismo y la clase trabajadora argentina. Buenos Aires: Siglo XXI, 2013.

MAUNÁS, Delia. Boris Spivacow - Memoria de un sueño argentino. Buenos Aires: Ediciones Colihue, 1995.

NEIBURG, Federico. Os intelectuais e a invenção do peronismo. São Paulo: EDUSP, 1997.

NOVARO, Marcos. Historia de la Argentina - 1955-2000. Buenos Aires: Siglo XXI, 2016.

NOVARO, Marcos (org.). Peronismo y democracia: historia y perspectivas de una relación compleja. Buenos Aires: Edhasa, 2014.

RODRÍGUEZ, Laura Graciela. Universidad, peronismo y dictadura. Buenos Aires: Prometeo Libros, 2015.

ROMERO, Luis Alberto. Breve historia contemporánea de la Argentina. Buenos Aires: Fondo de Cultura Económica, 2015.

SAGASTIZÁBAL, Leandro de. La edición de libros en la Argentina: una empresa de cultura. Buenos Aires: EUDEBA, 1995. 
SAGASTIZÁBAL, Leandro de. 50 años de libros para todos. Buenos Aires: EUDEBA, 2008.

SARLO, Beatriz e ALTAMIRANO, Carlos. La batalla de las ideas (1943-1973). Buenos Aires: Emecé Editores, 2007.

SIGAL, Silvia. Intelectuales y política en Argentina: la década del sesenta. Buenos Aires: Siglo XXI, 2001.

SIGAL, Silvia; VERÓN, Eliseo. Perón o muerte: los fundamentos discursivos del fenómeno peronista. Buenos Aires: EUDEBA, 2014.

SORÁ, Gustavo. Editar desde la Izquierda en la América Latina: la agitada historia del Fondo de Cultura Económica y de Siglo XXI. Buenos Aires: Siglo XXI, 2017.

SOUZA, Camilla Fontes de. La acción cambiante: da luta armada aos direitos humanos nos cartazes argentinos (1973-1984). Dissertação de Mestrado. 2013. Faculdade de Filosofia, Letras e Ciências Humanas da Universidade de São Paulo (FFLCH-USP).

TCACH, César. De la Revolución Libertadora al Cordobazo: Córdoba, el rostro anticipado del país. Buenos Aires: Siglo XXI, 2012.

TERÁN, Oscar. Historia de las ideas en la Argentina: diez lecciones iniciales. Buenos Aires: Siglo XXI, 2015.

TERÁN, Oscar. “Imago Mundi”, Punto de Vista, año XI, número 33 (sept-dic. 1988), pp. 3-7.

TERÁN, Oscar. Nuestros años sesentas. Buenos Aires: Siglo XXI, 2013.

VEZETTI, Hugo. Pasado y presente: guerra, dictadura y sociedad en la Argentina. Buenos Aires: Siglo XXI, 2009.

VEZETTI, Hugo. Sobre la violencia revolucionaria. Buenos Aires: Siglo XXI, 2013.

ZAROWSKY, Mariano. Nueva izquierda, sociología y medios de comunicación: itinerário de Heriberto Muraro en los años sesenta y setenta. IX Jornadas de Sociología de la UNLP. 2016. Ensenada, Argentina. Disponível em:

$<$ http://jornadassociologia.fahce.unlp.edu.ar/ix-jornadas/actas-

2016/PONmesa11Zarowsky.pdf>. Acesso em: 21 de janeiro de 2020. 